\title{
Scavenging of nickel and chromium toxicity in Aulosira fertilissima by immobilization: Effect on nitrogen assimilating enzymes
}

\author{
Meenakshi Banerjee* \\ Laboratory of Algal Biotechnology \\ Department of Biosciences \\ Barkatullah University \\ Bhopal-462026 (M.P.) \\ India \\ Tel: 917555287839 \\ E-mail: algal_biotech@yahoo.co.in \\ meenakshi_banerjee@indiatimes.com \\ Shanoo Mishra \\ Laboratory of Algal Biotechnology \\ Department of Biosciences \\ Barkatullah University \\ Bhopal-462026 (M.P.) \\ India \\ Tel: 91755254619 \\ E-mail: shanoomishra@yahoo.com \\ Jhuma Chatterjee \\ Laboratory of Algal Biotechnology \\ Department of Biosciences \\ Barkatullah University \\ Bhopal-462026 (M.P.) \\ India \\ Tel: 917553782295 \\ E-mail: jhuma_12@rediffmail.com
}

Keywords: Aulosira, chromium, immobilization, nickel, toxicity

The ubiquity of heavy metals in the biosphere results in the introduction of high amounts of toxic metals into the food chain from various sources. In the present study, one of the strongest nitrogen fixing cyanobacterium of the rice fields, Aulosira fertilissima, was subjected to nickel and chromium stress and the ameliorating effect of immobilization was investigated. Cell immobilization could protect the organism's growth against the toxicity of both heavy metals at $\mathrm{LC}_{50}$ as compared to lethal concentrations. The nitrate reductase activity in free cells treated with the metals was substantially inhibited but immobilized cells treated with $0.1 \mathrm{ppm}$ nickel was not affected by the metal treatment. Cell immobilization also resulted in a significant protection against sublethal concentration of chromium but to a lesser degree than it did with sub- lethal levels of nickel. Control immobilized cells also had higher Nitrogenase activity than control free cells. Nickel and chromium addition markedly decreased the enzyme activity in free cells but immobilized cells exposed to sublethal concentrations of both metals could overcome this decrease. Glutamine synthetase showed similar response under immobilized conditions compared to free cells with both metals. The addition of algal filtrate in 3:1 ratio further increased the nitrogenase activity compared with immobilized cells treated with sublethal doses of both metals. Immobilization facilitated higher uptake of nickel as compared to chromium. The observations of the present study clearly demonstrate the protective effect of immobilization on Aulosira fertilissima against Nickel and chromium toxicity. Rice field ecosystem thus possess a bidirectional natural metal ameliorating system where Aulosira mats act as a naturally immobilized system and the decay of Aulosira along with other cyanobacteria act as natural chelators protecting the rice plants from deleterious effects of the heavy metals. Most importantly is that the immobilization process protects the cyanobacterial nitrogen fixing process allowing it to maintain nitrogen economy of the fields in spite of the presence of heavy metals.

Heavy metals are ubiquitous in the biosphere where they

\footnotetext{
Corresponding author
} 
occur as part of the natural constituents of chemicals to which biota and human beings are frequently exposed. This results in introduction of substantial amounts of potentially toxic metals into the food chain. Microorganisms form a group of inseparable interacting communities, which are subjected to such unfavourable alteration of the aquatic and other ecosystems. Cyanobacteria, a group of prokaryotic, photosynthetic nitrogen fixers are present in every ecological niche and therefore, exposed to the toxic effects of the metals. The effects of a few metals have been studied with respect to growth, nitrogenase activity and carbon fixation, (Ting et al.1990; Cano et al. 1993; Gambrell, 1994; Blackwell et al. 1995; Chuan and Liu, 1996; James, 1996; Bohme, 1998; Kimbrough et al. 1999; Zaccaro et al. 1999; Barman et al. 2000; Kisku et al. 2000; Kotas and Stasicka, 2000; Suresh Babu et al. 2000; Armienta et al. 2001; Epniewska and Bucior, 2001; Suresh Babu et al. 2001). What has not been attempted is the study of naturally immobilized cyanobacteria such as Aulosira fertilissima, in ameliorating toxicity using similar immobilized conditions in the laboratory. This paper discusses the role of immobilization in ameliorating nickel and chromium toxicity on the enzymes of the nitrogen assimilating pathway in treated and non-treated cells and under free cell conditions. Additional role of algal filtrate has also been studied and compared to immobilized cells for their potential to mitigate the toxicity of the metals.

Table 1. Percentage increase in nitrogenase activity in immobilized cells in comparison to free cells.

\begin{tabular}{|c|c|}
\hline Conditions & \% Increase \\
\hline Control & $11.34 \%$ \\
\hline Nickel & $75.41 \%$ \\
\hline Chromium & $82.76 \%$ \\
\hline
\end{tabular}

\section{MATERIALS AND METHODS}

\section{Incubation and maintenance of culture}

Aulosira fertilissima was obtained from Indian Agriculture Research Institute, New Delhi, India and was cultured in Fogg's ( $\left.\mathrm{N}^{-}\right)$medium (1949). The cultures were kept in an air-conditioned culture room, which was illuminated by three $40 \mathrm{~W}$ fluorescent tubes at a distance of $50 \mathrm{~cm}$ for 12 hrs daily. The cultures received 2500- 3000 Lux light intensity and a temperature of $27 \pm 2^{\circ} \mathrm{C}$.

\section{Immobilization procedure}

Algal cultures were agitated vigorously with sterilized glass beads in test tubes, to disrupt the clumps formed. The separated algal filaments were harvested by centrifugation. Immobilization was done by the cell entrapment method using calcium alginate as described by Singh et al. 1989. The beads thus formed were washed with doubled distilled water and suspended in culture media containing different concentrations of metal solutions. A control-immobilized sample was also taken in which none of the heavy metals were added. Similarly, the free cell suspension of Aulosira fertilissima was also subjected to heavy metal treatment. $\mathrm{LC}_{50}$ values of the organisms for nickel and chromium were determined by standard plate count method with an exposure time to the metals equivalent to the generation (doubling) time of the organism i.e. 65 hrs. Sub lethal concentrations of nickel and chromium were used in all further experiments.

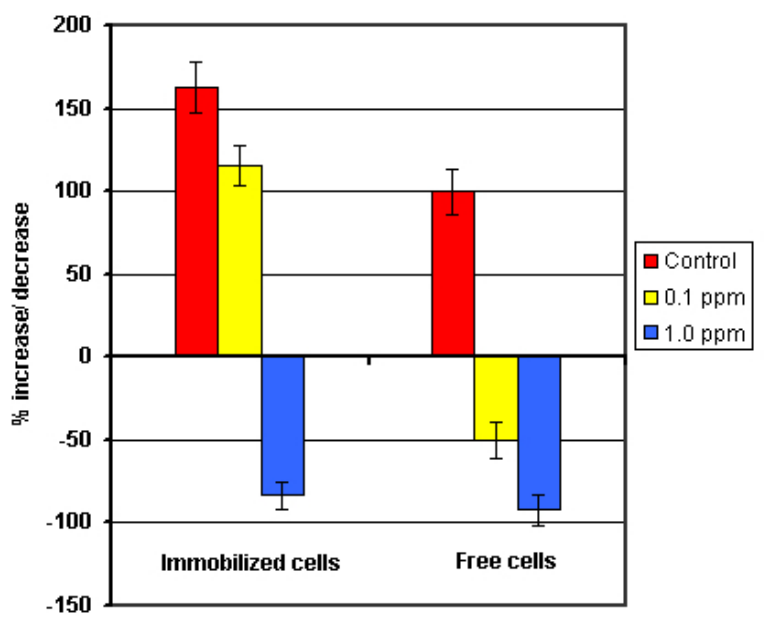

Figure 1. Percentage increase/decrease in growth of $\mathrm{Ni}$ treated immobilized and free cells of Aulosira fertilissima compared to free cells $\left(\mu \mathrm{g} \mathrm{Chl} \mathrm{a} \mathrm{l}^{-1}\right)$.

\section{Metal solution}

Nickel and chromium solutions with different concentrations were prepared by dissolving $\mathrm{NiCl}_{2} \cdot 6 \mathrm{H}_{2} \mathrm{O}$ and $\mathrm{K}_{2} \mathrm{Cr}_{2} \mathrm{O}_{7}$ in double distilled water and were filtered with $0.45 \mu$ Millipore filter before adding to the medium.

\section{Growth measurement}

Growthexperiment was carried out in culture tubes each containing $10 \mathrm{ml}$ basal medium. The growth was measured by Chlorophyll extraction. Chlorophyll was extracted in 10 $\mathrm{ml}$ of either $100 \%$ methanol or $80 \%$ acetone. The tubes were shaken for $5 \mathrm{~min}$ and then placed overnight in dark, in a refrigerator so as to ensure complete extraction. The optical density of the extract was measured with a Systronic 169 spectrophotometer at $663 \mathrm{~nm}$. The amount of Chlorophyll extracted was calculated according to the equation of Mackinney, 1941.

Chlorophyll $\mu \mathrm{g} / \mathrm{ml}=$ optical density $\times 12.63 \times$ dilution factor

The generation time was calculated by growth equation of 
Kratz and Myers, 1955.

$$
K=\frac{2.303\left(\log N_{2}-\log N_{1}\right)}{T_{2}-T_{1}}
$$

Where, $\mathrm{N}_{1}=$ Initial OD / Protein concentration at time $\mathrm{T}_{1}$, and $\mathrm{N}_{2}=$ Final OD/ Protein concentration at time $\mathrm{T}_{2}$.

\section{Nitrate reductase measurement}

The estimation of in vivo nitrate reductase activity was measured by the method of Camm and Stein, 1974 and as slightly modified by Kumar and Kumar, 1980. The activity is based on the total nitrite formed. For the estimation of enzyme activity known amount of algal suspension was centrifuged and washed 3-4 times with sterile double distilled water and suspended in culture medium containing $5 \mathrm{mM} \mathrm{NaNO}$. For different intervals, different sets of culture tubes containing $1 \mathrm{ml}$ of culture (final) were incubated. Standard curve was plotted with varying concentrations of $\mathrm{NaNO}_{2}$ dissolved in test medium. The nitrite present in the sample was expressed in $\mu \mathrm{g} \mathrm{NaNO}_{2} /$ $\mu \mathrm{g}$ Chl a using a standard curve.

\section{Glutamine synthetase measurement}

Estimation of Glutamine synthetase activity was done by $\gamma$ glutamyl transferase as described by Shapiro and Stadman, 1970, modified by Stacey et al. 1977. A standard of different concentration of glutamyl hydroxamate was prepared and optical density was read at $540 \mathrm{~nm}$. The transferase activity was calculated as $\mu$ mole $\gamma$ - glutamyl hydroxamate $\mu \mathrm{g}^{-1} \mathrm{Chl} \mathrm{ah}{ }^{-1}$.

Table 2. Percentage increase in glutamine synthetase activity in immobilized cells in comparison to free cells.

\begin{tabular}{|c|c|}
\hline Conditions & \% Increase \\
\hline Control & $40.91 \%$ \\
\hline Nickel & $81.25 \%$ \\
\hline Chromium & $93.10 \%$ \\
\hline
\end{tabular}

\section{Nitrogenase measurement}

Nitrogenase activity was measured by Acetylene Reduction Assay given by Stewart et al. 1968. Aliquots $(2 \mathrm{ml})$ of exponentially growing cultures were placed in $8 \mathrm{ml}$ vacutainer tubes and sealed with washed serum stoppers. $10 \%$ acetylene gas was injected into the tubes. Reaction was run for $60 \mathrm{~min}$ at $28^{\circ} \mathrm{C}$ and $2500 \mathrm{Lux}$. The reaction was terminated by injecting $0.2 \mathrm{ml}$ of $2 \mathrm{~N} \mathrm{NaOH}$. The ethylene produced was analyzed in a Gas Liquid Chromatograph fitted with a Porapak R. column and a hydrogen flame ionization detector. Nitrogenase activity was expressed in terms of n moles $\mathrm{C}_{2} \mathrm{H}_{4} \mu \mathrm{g}^{-1} \mathrm{Chl} \mathrm{ah}{ }^{-1}$.

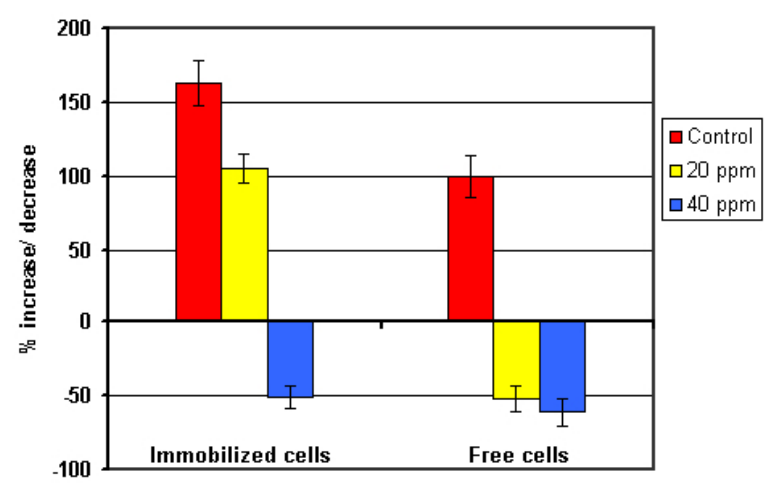

Figure 2. Percentage increase/decrease in growth of $\mathrm{Cr}$ treated immobilized and free cells of Aulosira fertilissima compared to free cells $\left(\mu \mathrm{g} \mathrm{Chl} \mathrm{a} \mathrm{l}^{-1}\right)$.

\section{Metal uptake studies}

The uptake of nickel and chromium was under-taken in an Atomic Absorption Spectrophotometer Model 2380 Perkin Elmer and expressed in $\mathrm{mgl}^{-1}$ by the method described by Singh et al. 1989. The result has been calculated by the difference observed in the concentration of both metals comparing the initial value $\left(\mathrm{mgl}^{-1}\right)$ added in culture medium containing the cyanobacterium/immobilized beads and the value $\left(\mathrm{mgl}^{-1}\right)$ remaining in the medium after 8 days.

\section{Toxicity mitigating studies}

The amelioration of heavy metal toxicity was studied with algal filtrate. The algal filtrate was prepared by centrifuging two months old cultures of Aulosira fertilissima. This filtrate was added in different ratios to the medium, i.e. 25:75, 50:50, 75:25 and 100. Best results were obtained in $75: 25$ ratio and therefore shown in this study.

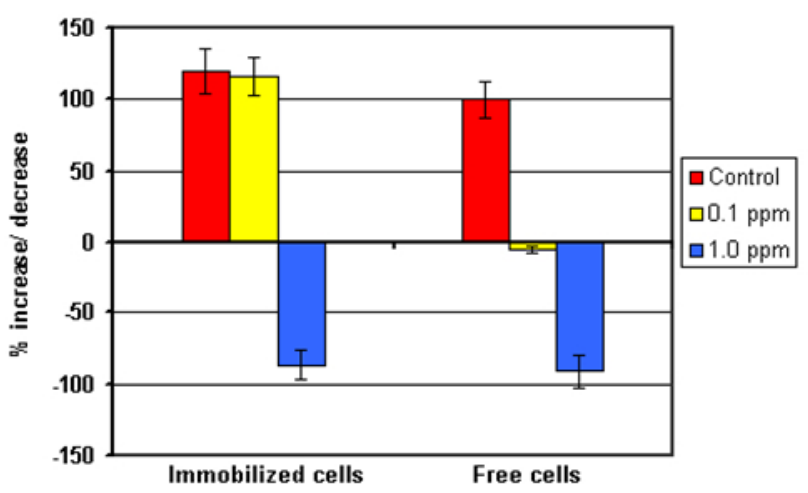

Figure 3. Percentage increase/decrease in nitrate reductase activity of $\mathrm{Ni}$ treated immobilized and free cells of Aulosira fertilissima compared to free cells $\left(\mu \mathrm{g} \mathrm{NO}_{2} \mathrm{Chl} a^{-1}\right)$. 


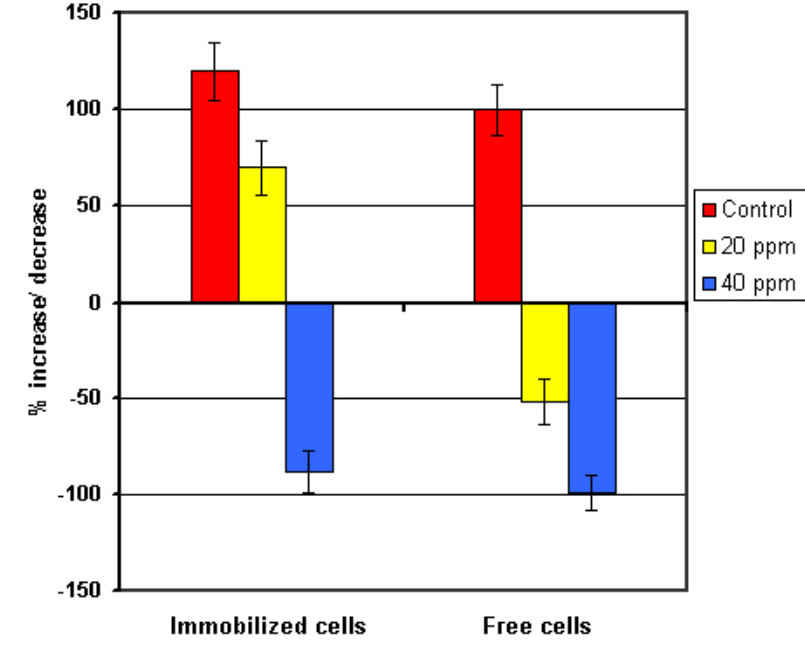

Figure 4. Percentage increasel decrease in nitrate reductase activity of $\mathrm{Cr}$ treated immobilized and free cells of Aulosira fertilissima compared to free cells $\left(\mu \mathrm{g} \mathrm{NO} \mathrm{Chl} \mathrm{a}^{-1}\right)$.

Comparative studies between immobilized and free cells were made with 9 alginate beads containing the algal cells and $2 \mathrm{ml}$ of free cells in culture media. The beads were made in such a way that 9 of them and $2 \mathrm{ml}$ of free suspended cells contained the same amount of Chlorophyll a $(0.12 \mathrm{mg})$ at 0 hour.

\section{RESULTS}

The growth of Aulosira fertilissima was significantly inhibited with the increasing concentrations of the heavy metals. $\mathrm{LC}_{50}$ value of the organism for nickel was found to be $0.1 \mathrm{ppm}$ and that of chromium was $20 \mathrm{ppm}$ after exposure to the metals for a period equivalent to the generation time of the cyanobacterium. After the eighth day of inoculation, immobilized control cultures showed $63 \%$ increase in growth over free control cells. Further, it was observed that immobilization has significant protective effect on growth against the toxicity of the heavy metals at sub- lethal concentrations of both metals (Figure 1 and Figure 2). Immobilization restored growth of Aulosira fertilissima as compared to free cells under $0.1 \mathrm{ppm}$ nickel treatment. This was followed by immobilized cell treated with $20 \mathrm{ppm}$ chromium (5\% increase). No significant protection to growth was obtained by immobilization with lethal concentration of the metals i.e. $1 \mathrm{ppm}$ of nickel and $40 \mathrm{ppm}$ of chromium.

Nitrate reductase activity of free and immobilized cells was also studied (Figure 3 and Figure 4). The enzyme activity in free cells treated with nickel and chromium was substantially inhibited. Immobilization enabled Aulosira fertilissima to not only overcome the toxicity but also to enhance nitrate reductase activity when exposed to $0.1 \mathrm{ppm}$ nickel. The protection however was less in sublethal concentrations of chromium treated cells. In contrast, no restoration of the enzyme activity was noted due to immobilization when Aulosira fertilissima was treated with lethal concentrations of both nickel and chromium.

Table 3. Percentage increase in nitrogenase activity in free cells treated with $3: 1$ algal filtrate in comparison to free cells.

\begin{tabular}{|c|c|}
\hline Conditions & \% Increase \\
\hline Control & $15.46 \%$ \\
\hline Nickel & $80.33 \%$ \\
\hline Chromium & $87.93 \%$ \\
\hline
\end{tabular}

Nitrogenase activity in Aulosira fertilissima with and without nickel and chromium in free and immobilized cells gave some interesting results (Figure 5). Nitrogenase activity was higher in control immobilized cells than in control free cells. Although, the activity with nickel and chromium markedly decreased in heavy metal- treated free cells, this decrease was overcome in the treated immobilized cells, and the activity was similar to the control immobilized cells. Table 1 reveals the percentage increase in nitrogenase activity in immobilized cells in comparison to free cells.

Very similar observations where obtained when glutamine synthetase activity was studied in which immobilization was found to have a protective effect against metal toxicity compared to free cells especially under sublethal conditions, (Figure 6).

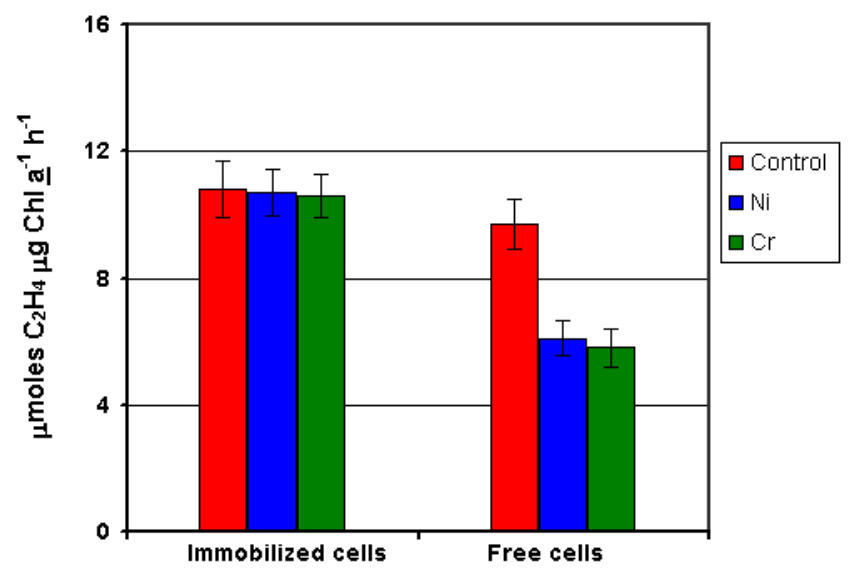

Figure 5. Comparative nitrogenase activity in immobilized and free cells of Aulosira fertilissima subjected to $\mathrm{Ni}$ and $\mathrm{Cr}$ toxicity (sub-lethal doses) at $\mathbf{9 6} \mathrm{hrs}$.

Table 2 shows the percentage increase in glutamine synthetase activity in immobilized cells in comparison to free cells.

Aulosira is known for its high rates of nitrogen fixation in rice fields and therefore nitrogenase activity was also studied in the presence of metals, under immobilized conditions and free cells along with algal filtrate in the ratio 
Table 4. Uptake of nickel and chromium added to the medium as lethal doses after 8 days of growth of free cells and immobilized cells of Aulosira fertilissima.

\begin{tabular}{|c|c|c|c|c|c|c|}
\hline Condition & \multicolumn{3}{|c|}{ Nickel } & \multicolumn{3}{|c|}{ Chromium } \\
\hline & $\begin{array}{l}\text { Initial conc. of } \mathrm{Ni} \text { in the } \\
\text { medium }\end{array}$ & $\begin{array}{l}\text { Final conc. of } \mathrm{Ni} \text { in the } \\
\text { medium after } 8 \text { days }\end{array}$ & \multirow{2}{*}{$\begin{array}{l}\text { Percentage } \\
\text { uptake }\end{array}$} & $\begin{array}{l}\text { Initial conc. of } \mathrm{Cr} \text { in the } \\
\text { medium }\end{array}$ & $\begin{array}{l}\text { Final conc. of } \mathrm{Cr} \text { in the } \\
\text { medium after } 8 \text { days }\end{array}$ & \multirow{2}{*}{$\begin{array}{l}\text { Percentage } \\
\text { uptake }\end{array}$} \\
\hline & \multicolumn{2}{|c|}{$\left(\right.$ in $\left.\mathrm{mg} \mathrm{I}^{-1}\right)$} & & \multicolumn{2}{|c|}{$\left(\right.$ in $\left.\mathrm{mg} \mathrm{I}^{-1}\right)$} & \\
\hline $\begin{array}{l}\text { Immobilized } \\
\text { cells }\end{array}$ & 0.001 & 0.00011 & $89 \%$ & 0.020 & 0.0009 & $55 \%$ \\
\hline
\end{tabular}

of 3:1 (Figure 7). The results show that addition of algal filtrate could enhance nitrogenase activity even more than what was observed with immobilized cells treated with 0.1 ppm nickel. This enhancement was much higher than the control free cells. In chromium treated cells, addition of algal filtrate also further enhanced the enzyme activity but it was less than with nickel.

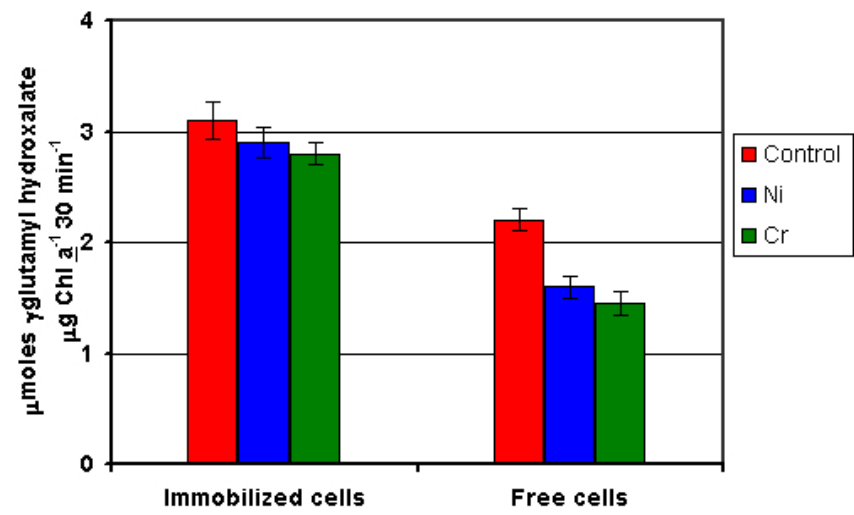

Figure 6. Comparative glutamine synthetase activity in immobilized and free cells of Aulosira fertilissima subjected to $\mathrm{Ni}$ and $\mathrm{Cr}$ toxicity (sub-lethal doses) at $96 \mathrm{hrs}$.

Table 3 shows the percentage increase in nitrogenase activity in free cells treated with $3: 1$ algal filtrate in comparison to control free cells.

Uptake studies of metals showed higher uptake of both metals by immobilization (Figure 8 and Table 4).

Nickel was taken up at higher rates than chromium in Aulosira fertilissima.

\section{DISCUSSION}

The observations in the present study clearly indicate a protective effect of immobilization on Aulosira fertilissima against nickel and chromium toxicity. The mechanism of toxicity of metals to cyanobacteria are not fully known but several heavy metals retard the flow of electrons in electron transfer reaction in mitochondria and chloroplast and thus can be expected to have a detrimental effect on respiration, photosynthesis and other processes related to it. The observed protection due to calcium alginate immobilization on Chlorophyll a content, nitrate reductase activity, nitrogenase and glutamine synthetase at $20 \mathrm{ppm}$ of chromium and $0.1 \mathrm{ppm}$ of nickel could be due to the metal binding capacity of alginate. Alginate, which is a mixture of polyguluronic acid and polymannuronic acid, has abundant hydroxyl groups which bind the metal ions and prevent them from entering the cells in full concentration thereby protecting against the decrease of Chlorophyll a content and enzyme activities as observed in free cells. Banerjee and Mishra, 2002 have also shown the mitigating effect of immobilization on cyanobacteria subjected to heavy metal stress.

Basically, immobilization brings about increase in growth by producing direct contact between cell and medium, thus increasing the surface area available for various cellular reactions. On the other hand, the increase in nitrate reductase activity maybe due to change in the cellular behavior by directly modifying the intrinsic characteristics of the culture as beads by forming a monolayer on the surface of the culture medium thus increasing not only surface area but also increasing availability of other important environmental parameters like light and oxygen concentration,(Banerjee and Mishra, 2002; Marsac and Houmard, 1993).

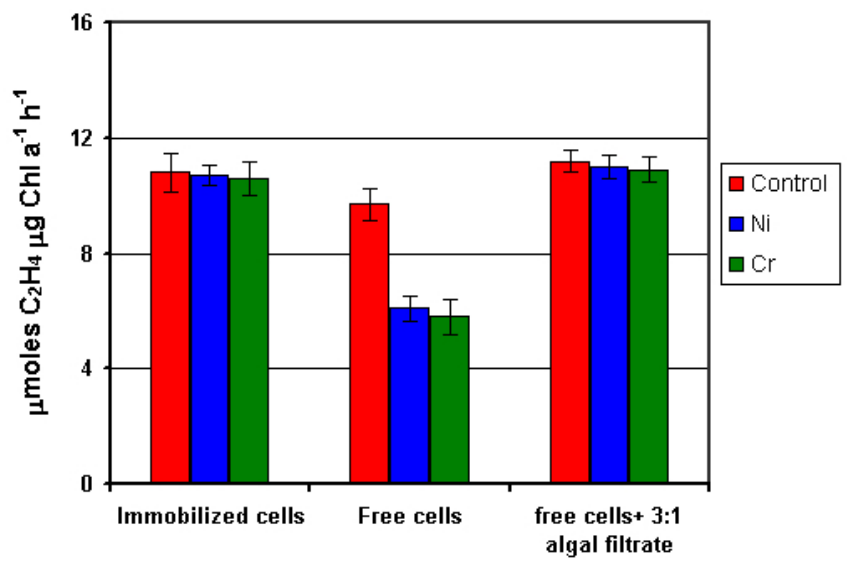

Figure 7. Comparative nitrogenase activity in immobilized cells, free cells and free cells treated with algal filtrate of Aulosira fertilissima subjected to $\mathrm{Ni}$ and $\mathrm{Cr}$ toxicity (sub-lethal doses).

The increase in nitrate reductase, nitrogenase and glutamine 
synthetase activity in nickel treated cells might be due to increase in surface area of thylakoids, thereby increasing the photosynthetic potential by active synthesis of thylakoidal protein and associated pigments (Trehan and Maneesha, 1991). This, on the other hand, produces the stimulatory effect on nitrate reductase because of increased reductant supply on which the enzyme is naturally dependent.

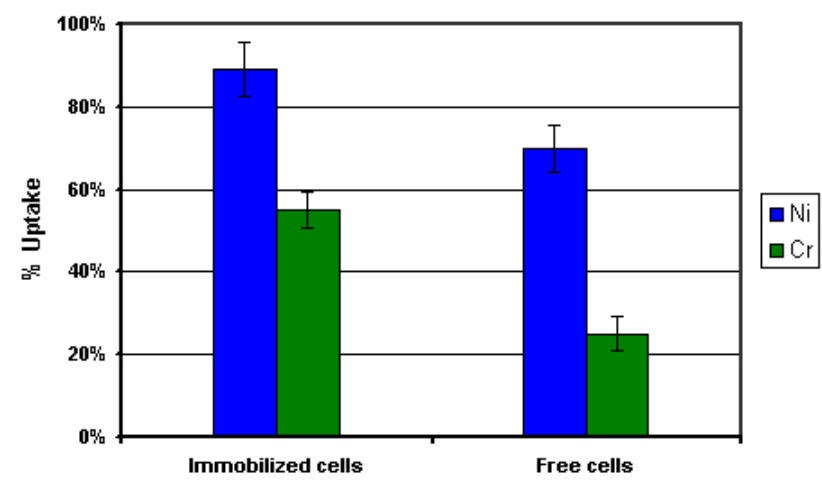

Figure 8. Uptake of $\mathrm{Ni}$ and $\mathrm{Cr}$ added to the medium as lethal doses after 8 days of growth of free cells and immobilized cells of Aulosira fertilissima.

Chromium failed to stimulate the nitrate reductase activity in lethal doses because chromium is known to inhibit protein synthesis (Rai and Dubey, 1988) and so it might be interfering with nitrate reductase synthesis causing the failure of immobilization to stabilize nitrate reductase activity. It however, had a stimulatory effect on nitrate reductase, nitrogenase and glutamine synthetase in sublethal doses. In fact, under immobilized conditions the toxicity of chromium to the enzymes in free cells was overcome suggesting that chromium may have been restricted from entering the cells by metal binding ligands in alginate.

The observations that the addition of the algal filtrate had marked stimulatory effect comparable to immobilized control cells with nickel and chromium suggest the complexing of the metals with organic extracellular material in the filtrate, (Srivastava et al. 1999a, Srivastava et al. 1999b). The slightly higher activity with the filtrates compared to immobilized cells can be attributed to the presence of other bioactive substances in the filtrate which in turn stimulate the enzyme activity. Cyanobacteria are known to release organic substances that can chelate free metal ions. The analysis of algal filtrate of Aulosira fertilissima revealed the presence of some major amino acids along with polysaccharides. Banerjee and Sharma, 1994 also reported the mitigating effect of algal filtrate on Lead toxicity in Anabaena flos aquae.The presence of methionine as one of the amino acids is very significant, which may result in binding of the metals with sulphydryl groups. Further, the polysaccharides may act as chelators,
(Caire et al. 1997; Krajnc et al. 1995).

The uptake of both the metals was higher in immobilized condition in comparison to free cells, due to the presence of abundant hydroxyl groups in the alginate, which bind the metal ions. Similar effects were observed by Brun et al. 1998; Gloaguen et al. 1996; Ye et al. 1997.

\section{CONCLUDING REMARKS}

Rice field ecosystems possess a bidirectional natural metal ameliorating system where Aulosira mats act as immobilized cells and decay of Aulosira and other cyanobacteria act as natural chelators protecting the rice plants from the deleterious effects of heavy metals. The presence of nickel and chromium at sub-lethal levels as used in this study, which under natural environments is not negligible, could very effectively be removed from the proximity of the cyanobacteria in the fields by its own natural mechanism. This is very significant for India as the rice fields get their water for irrigation from sources that are often highly contaminated with these two metals as a result of dumping of idols and other effluents from paint, tannery and leather industries. The presence of these metals could have a direct bearing on the nitrogen economy of these fields if the cyanobacteria are adversely affected.

\section{REFERENCES}

ARMIENTA, M.A.; MORTON O.; RODRIGUEZ, R.; CRUZ, O.; AGUAYO, A. and CENICEROS, N. chromium in a tannery wastewater irrigation area. Bulletin of Environmental Contamination and Toxicology, 2001, vol. 66, no. 2, p. 189-195.

BANERJEE, M. and MISHRA, S. Mitigating effect of immobilization on Aulosira fertilissima subjected to nickel and chromium stress. Bulletin of Bioscience, 2002, vol. 1, p. 43-46.

BANERJEE, M. and SHARMA, A. Mitigating effect of algal filtrate on Lead toxicity in Anabaena flos aquae. Pollution Research, 1994, vol. 13, no. 1, p. 59-62.

BARMAN, S.C.; SAHU, R.K.; BHARGAVA, S.K. and CHATTERJEE, C. Distribution of heavy metals in wheat, mustard and weeds grown in field irrigated with industrial pollutants. Bulletin of Environmental Contamination and Toxicology, 2000, vol. 64, p. 489-496.

BLACKWELL, K.J.; SINGLETON, I. and TOBIN, J. M. Metal cation uptake by yeast: a review. Applied Microbiology and Biotechnology, 1995, vol. 43, p. 579584.

BOHME, H. Regulation of nitrogen fixation in heterocystforming cyanobacteria. Trends in Plant Science, 1998, vol. 3, no. 9, p. 346- 351 . 
BRUN, L.A.; MAILLET, J.; RICHARTE, J.; HERRMANN, P. and REMY, J.C. Relationships between extractable copper, soil properties and copper uptake by wild plants in vineyard soils. Environmental Pollution, 1998, vol. 102, p. 151-161.

CAIRE, G; STORNI DE CANO, M.; ZACCARO DE MULE, M.C. PALMA R.M. and COLOMBO, K. Exopolysaccharides of Nostoc muscorum Ag. (Cyanobacteria) in the aggregation of soil particles. Journal of Applied Physiology, 1997, vol. 9, p. 249-253.

CAMM, E.L. and STEIN, J.R. Some aspects of nitrogen metabolism of Nodularia spunigena (cyanophyceae). Canadian Journal of Botany, 1974, vol. 52, p. 719-726.

CANO, M.; ZACCARO DE MULE, M.C.; CAIRE, G. and HALPERIN, D. Biofertilization of rice plants with the cyanobacterium Tolypothrix tenius (40d.). International Journal of Experimental Botany (Phyton), 1993, vol. 54, no. 2, p. 149-155.

CHUAN, M.C. and LIU, J.C. Release behavior of chromium from tannery sludge, Water Research, 1996, vol. 30, p. 932-938.

EPNIEWSKA, Z. and BUCIOR, K. chromium contamination of soils, waters and plants in the vicinity of a tannery waste lagoon. Environmental and Geochemical Health, 2001, vol. 23, p. 241-245.

GAMBRELL R.P. Trace and toxic metals in wetlands-a review. Journal of Environmental Quality, 1994,vol.23, p. 883-891.

GLOAGUEN, V.; MORVAN, H. and HOFFMANN, L. Metal accumulation by immobilized cyanobacterial mats from a thermal spring. Journal of Environmental Science and Health, 1996, vol. A31, no. 10, p. 2437-2451.

JAMES, B.R. The challenge of remediating chromium contaminated soil. Environmental Science and Technology, 1996, vol. 30, p. 248-251.

KIMBROUGH, D.E.; COHEN, Y.; WINER, A.M.; CREELMAN, L. and MABUNI, C. A critical assessment of chromium in the environment. Critical Review of Environmental Science and Technology, 1999, vol. 29, p. 144.

KISKU, G.C.; BARMAN, S.C. and BHARGAVA, S.K. Contamination of soil and plants with potentially toxic elements and its impact on the environment. Water, Air, Soil Pollution, 2000, vol. 120, no. 1-2, p. 121-137.

KOTAS, J. and STASICKA, Z. chromium occurrence in environment and methods of its speciation. Environmental Pollution, 2000, vol. 107, no. 3, p. 263-283.

KRAJNC, M.; STUPAR, J. and MILICEV, S. Characteristics of chromium and Copper Complexes with Fulvic Acids Isolated from Soils in Slovenia. Science of the Total Environment, 1995, vol. 159, p. 23-31.

KUMAR, A. and KUMAR, H.D. Tungsten induced inactivation of molybdoenzyme in Anabaena. Biochemical Biophysical Acta, 1980, vol. 613, p. 244-248.

MACKINNEY, G. Absorption of light by chlorophyll solution. Journal of Biological Chemistry, 1941, vol. 140, p. 315-322.

MARSAC, DE TANDEAU and HOUMARD, J. Adaptation of cyanobacteria to environmental stimuli: New steps towards molecular mechanism. FEMS Microbiology Reviews, 1993, vol. 104, p. 119-190.

RAI, L.C. and DUBEY, S.K. chromium toxicity to a cyanobacterium: possible role of carbon sources in toxicity amelioration. Microbios, 1988, vol. 55, p. 193-203.

SHAPIRO, B.M. and STADMAN, K.R. Glutamine synthetase (Escherichia coli). Methods in Enzymology. Academic Press New York, 1970, vol. 17, p. 910-922.

SRIVASTAVA, S.; NIGAM, R.; PRAKASH, S. and SRIVASTAVA, M.M. Mobilization of trivalent chromium in presence of organic acids: A hydroponic study of wheat plant (Triticum Vulgare) Bulletin of Environmental Contamination and Toxicology, 1999a, vol. 63, no. 4, p. 524-530.

SRIVASTAVA, S.; PRAKASH, S. and SRIVASTAVA, M.M. chromium mobilization and plant availability-impact of Organic complexing ligands. Plant and Soil, 1999b, vol. 212 , no. 2, p. 203-208.

SINGH, S.P.; VERMA, S.K.; SINGH, R.K. and PANDEY P.K. Copper uptake by free and immobilized cyanobacterium. FEMS Microbiological Letters, 1989, vol. 60, p. 193-196.

STACEY, G.; TABITA, F.R. and VAN BAALEN, C. Nitrogen and ammonia assimilation in the cyanobacteria: purification of glutamine synthetase from Anabaena sp. Strain C.A. Journal of Bacteriology, 1977, vol. 132, p. 596603.

STEWART, W.D.P.; FITZGERALD, G.P. and BURRIS, R.H. Acetylene reduction by nitrogen fixing blue green algae. Archives of Microbiology, 1968, vol. 62, p. 336-348.

SURESH BABU, G.; FAROOQ, M.; SINGH, J.; VISHWANATHAN, P.N.; JOSHI, P.C. and HANS, R.K. 
Metabolic alterations due to exposure of lindane in Basmati rice (Oryza sativa) seedlings. Pollution Research, 2000, vol. 19, p. 523-528.

SURESH BABU, G.; HANS, R.K.; SINGH, J.; VISHWANATHAN, P.N. and JOSHI, P.C. Effect of lindane on growth and metabolic activity of cyanobacteria. Ecotoxicology and Environmental Safety, 2001, vol. 48, no. 2, p. 219-221.

TING, Y.P.; LAWSON, F. and PRINCE, I.G. The uptake of heavy metals ions by algae. Australian Journal of Biotechnology, 1990, vol. 4, p. 197-200.

TREHAN, K. and MANEESHA, A. Effect of Lead on nitrogenase and enzymes of nitrogen assimilation in a cyanobacterium Nostoc muscorum. Indian Journal of Experimental Biology, 1991, vol. 29, p. 1116-1119.

YE, Z.H.; BAKER, A.J.M.; WONG, M.H. and WILLIS, A.J. Zinc, lead and cadmium tolerance, uptake and accumulation in populations of Phragmites australis (Cav.) Trin. ex Steudel. Annals of Botany, 1997, vol.80, p. 363370.

ZACCARO DE MULE, M.C.; CAIRE, G.; CANO, M.; PALMA, M. and COLOMBO, K. Effect of cyanobacterial inoculation and fertilizers on rice seedlings and post harvest soil structure. Communication in Soil Science and Plant Analysis, 1999, vol. 30, no. 1-2, p. 97-107. 